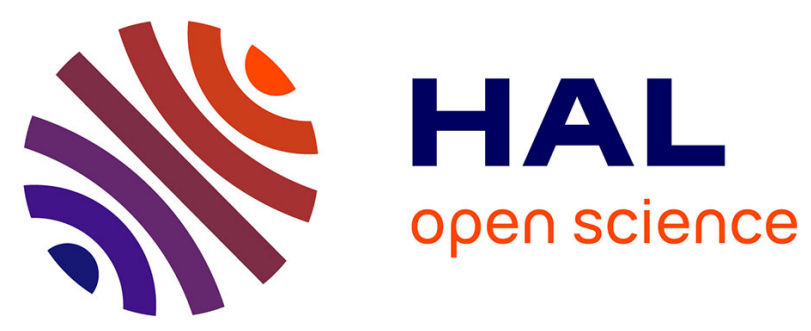

\title{
Differences in branch characteristics of Scots pine (Pinus sylvestris L.) genetic entries grown at different spacing
} Jaume Gort, Ane Zubizarreta-Gerendiain, Heli Peltola, Antti Kilpeläinen, Pertti Pulkkinen, Raimo Jaatinen, Seppo Kellomäki

\section{- To cite this version: \\ Jaume Gort, Ane Zubizarreta-Gerendiain, Heli Peltola, Antti Kilpeläinen, Pertti Pulkkinen, et al.. Differences in branch characteristics of Scots pine (Pinus sylvestris L.) genetic entries grown at different spacing. Annals of Forest Science, 2010, 67 (7), 10.1051/forest/2010030 . hal-00883632}

\section{HAL Id: hal-00883632 \\ https://hal.science/hal-00883632}

Submitted on 1 Jan 2010

HAL is a multi-disciplinary open access archive for the deposit and dissemination of scientific research documents, whether they are published or not. The documents may come from teaching and research institutions in France or abroad, or from public or private research centers.
L'archive ouverte pluridisciplinaire HAL, est destinée au dépôt et à la diffusion de documents scientifiques de niveau recherche, publiés ou non, émanant des établissements d'enseignement et de recherche français ou étrangers, des laboratoires publics ou privés. 


\title{
Differences in branch characteristics of Scots pine (Pinus sylvestris L.) genetic entries grown at different spacing
}

\author{
Jaume GorT $^{1 *}$, Ane Zubizarreta-Gerendiain ${ }^{1,2}$, Heli PeltolA ${ }^{1}$, Antti KilpeläIneN ${ }^{1}$, \\ Pertti PUlKKINEN ${ }^{3}$, Raimo JAATINEN ${ }^{3}$, Seppo KelloMÄKI ${ }^{1}$ \\ ${ }^{1}$ University of Eastern Finland, Faculty Sciences and Forestry, School of Forest Sciences, 80101 Joensuu, Finland \\ ${ }^{2}$ Present address: Centro de Estudo Florestais, Instituto Superior de Agronomia, Technical University of Lisbon, Tapada da Ajuda, \\ 1349-017 Lisboa, Portugal \\ ${ }^{3}$ Finnish Forest Research Institute, Haapastensyrjä Breeding Station, Karkkilantie 247, 12600 Läyliäinen, Finland
}

(Received 28 October 2009; accepted 4 February 2010)

\author{
Keywords: \\ spacing / \\ yield traits / \\ branch diameter / \\ branch angle / \\ cumulative branch area
}

\begin{abstract}
- We studied the differences in branch characteristics along the stems of six different genetic entries of 20 year old Scots pines (Pinus sylvestris L.) grown at different spacing (current stand density range 2000-4000 trees $\mathrm{ha}^{-1}$ ) in central Finland. Furthermore, we studied the phenotypic correlations between yield, wood density traits and branch characteristics. All the genetic entries had Kanerva pine (plus tree S1101) as a father tree, whereas the mother tree represented Finnish plus trees from southern, central and northern Finland.

- Spacing affected all yield traits, wood density and living branch characteristics such as relative average branch diameter and relative cumulative branch area $(p<0.05)$. As a comparison, genetic entry affected height, while origin group (southern, central and northern ones) affected most of the studied traits. Regardless of spacing, the northern origin had, on average, the largest stem diameter and highest wood density, while the central one was the tallest one. Furthermore, average branch diameter along the stem was affected by branch age, origin group and spacing, while average branch angle was affected by branch age and genetic entry $(p<0.05)$.

- In general the average branch size could be decreased especially in lower tree canopy by denser spacing during the early phase of the rotation, but only at the expense of tree growth. Correspondingly differences between origins are mainly related to their differences in stem growth.
\end{abstract}

\section{INTRODUCTION}

The value of the raw material for solid wood processing is affected by the stem volume and potential sawn timber quality (e.g. branch characteristics, knot properties and stem straightness). These traits are of primary importance in long-term tree breeding programmes for Scots pine (Pinus sylvestris L.) (Haapanen et al., 1997; Hannrup et al., 2000, Ståhl, 1988). Silvicultural management (e.g. control of initial spacing, tending of seedling stand and thinning) affects the radial growth of trees and consequently, the growth, mortality and self-pruning of branches along the stem, with implications for the properties of the sawn timber (see e.g. Ikonen et al., 2009). Because of the strong correlation between the growth of stem and branches in Scots pine, the reduction of branch size is only possible at the expense of total tree growth (e.g. Mäkinen, 1999a; Mäkinen and Colin, 1998).

In Scots pine, like in other coniferous species, the average size of living branches increases along the stem from the stem apex to the living crown base (Kellomäki et al., 1999; Mäkinen et al., 1999b). However, it is possible to control the growth

*Corresponding author: jaume.gort@uef.fi of the stem and branches in the middle and lower crown by controlling the light competition, especially in the early phase of the rotation. This can be done by the appropriate choice of initial spacing, timing and intensity of tending of seedling stand and/or first thinning. As a result, the quality of the most valuable lower part of the stem can be improved.

On the other hand, different genetic entries may show differences in their stem and branch characteristics (e.g. Haapanen et al., 1997; Velling, 1988), and their response to different management regimes may vary, to some degree, depending on the environmental conditions of the site (e.g. Zobel and Talbert, 1984). In Finland, tree breeders have paid special attention to a genetic entry called Kanerva pine (S1101), which was originally found in Punkaharju, in south-eastern Finland (lat. $61^{\circ} 43^{\prime} \mathrm{N}$, long. $28^{\circ} 25^{\prime} \mathrm{E}$, alt. $85 \mathrm{~m}$ ). About $50 \%$ of its offspring are characterised by a high growth rate, a high stem wood productivity, reduced stem tapering, narrow crown and short and thin branches with an insertion angle close to 90 degrees (e.g. Kärki, 1985; Pöykkö, 1993; Pöykkö and Velling, 1993). However, poor stem straightness is typically observed in Kanerva pine, although this undesired characteristic can be avoided by crossing Kanerva pine with other genetic entries possessing superior stem straightness. 
Table I. Genetic entries (GE) and geographical origins of the crossings between S1101 Kanerva pine (father) from Punkaharju (Southern Finland) with different mother trees.

\begin{tabular}{lcccc}
\hline GE & Entry & Crossing type & Site of mother trees & Origin Group \\
\hline 5 & C205 $\times$ S1101 & Controlled cross seed & Multia & Central Finland \\
6 & C214B $\times$ S1101 & Controlled cross seed & Äänekoski & Central Finland \\
9 & S2582 $\times$ S1101 & Controlled cross seed & Kuru & Southern Finland \\
10 & S104 $\times$ S1101 & Controlled cross seed & Tammela & Southern Finland \\
15 & N1924 $\times$ S1101 & Controlled cross seed & Taivalkoski & Northern Finland \\
16 & N334 $\times$ S1101 & Controlled cross seed & Kemijärvi & Northern Finland \\
\hline
\end{tabular}

Few studies exist on the phenotypic or genetic correlations between yield, stem quality traits (e.g. stem straightness, branch characteristics) and average wood density in Scots pine (Haapanen et al., 1997; Hannrup et al., 2000). In these studies, weak negative or no genetic/phenotypic correlations have been reported between traits such as branch angle, branch thickness, number of branches, stem straightness and average wood density. However, according to Hannrup et al. (2000), for example, relative branch diameter correlates positively with wood density in Scots pine. Previously, Velling (1988) suggested that if there is a preference for narrow-crowned Scots pine trees with fine branches and large branch angle this might lead to lower average wood density. Contradictory evidence exists in the literature for the relationship between growth rate and wood density in Scots pine. It has been found, that an increase in stem growth decreases the average wood density (Wilhelmsson et al., 2002), but a non-significant or a weak positive relationship between these traits has also been observed (Mörling, 2002). This has also been the case for lodgepole pine (Pinus contorta) (Wang et al., 2000).

The simultaneous effects of spacing and genetic entry on the yield traits, branch characteristics and wood density have not been previously studied in detail for Scots pine in Finland, as few experiments have been designed for this purpose. In this context, the main aim of this work was to study the differences in branch characteristics along the stem of six genetic entries (full-sib families) of 20 year old Scots pine trees grown at different spacing (with current stand density range of 2000 4000 trees/ha) in central Finland. Furthermore, we studied the phenotypic correlations between different yield traits, branch characteristics and average wood density. In our study, Kanerva pine (plus tree S1101) was one of the parent trees for all six genetic entries, while the other parent trees represent Finnish plus trees with a relatively wide geographical range from southern to northern Finland. Therefore, we expected differences in branch characteristics, as well as in other traits, between these crossings. The present research is continuous work for those shown previously by Gort et al. (2009) and Peltola et al. (2009), investigating the effects of spacing and genetic entry on the phenotypic variation of growth/yield and wood density traits and fibre properties in Scots pine.

\section{MATERIAL AND METHODS}

\subsection{Experimental data}

The material used in this study was obtained from a Scots pine spacing trial established in 1987 at Siilinjärvi (trial 1216/01) in cen- tral Finland $\left(63^{\circ} 06^{\prime} \mathrm{N}, 27^{\circ} 41^{\prime} \mathrm{E}, 1100\right.$ degree days, $85 \mathrm{~m}$ above sea level). This trial is located on agricultural soil (high fertility) and it consists of three different spacing treatments with initial stand densities of 2000, 4000 and 8000-8 200 seedlings ha ${ }^{-1}$. In autumn 2000, the tending of the seedling stand was done in this trial, excluding the widest spacing, which was left unmanaged (later referred to as spacing 1). The medium spacing was thinned to a stand density of 2000 2500 seedlings $\mathrm{ha}^{-1}$ (spacing 2) and the densest one was thinned to 4000 seedlings/ha (spacing 3). From this trial, in autumn 2008 altogether 6 of the 20 genetic entries (full-sib families) were harvested, with all of them having Kanerva pine (plus tree S1101) as a parent tree, whereas the other parent trees represented Finnish plus trees with a relatively wide geographical range from southern to northern Finland (Tab. I).

From each spacing and genetic entry, five sample trees were randomly harvested (Tab. I), i.e. a total of 90 sample trees. We measured tree height $(\mathrm{H}, \mathrm{m})$, stem diameter at both breast height $(\mathrm{DBH}, \mathrm{mm})$ and at $6 \mathrm{~m}$ height from the stem base (D6, mm) for each sample tree, and calculated the stem volume $\left(\mathrm{V}, \mathrm{m}^{3}\right)$ based on functions developed by Laasasenaho (1982) for Scots pine. Moreover, sample discs were cut at $1 \mathrm{~m}$ height from the stem base in each sample tree for the average wood density measurements.

Branch measurements started at the second whorl from the tree top followed by the measurements at every third whorl (i.e. whorls 2, 5 and 8). In each whorl, only the main living branches were measured (whereas small or dead branches were ignored). The distance of each whorl from the tree top was determined. Altogether, the following branch characteristics were measured: (i) branch diameter at one centimetre distance from stem insertion point (BD, mm), (ii) branch length (BL, cm) and (iii) branch insertion angle (BA, degrees) to the nearest $10^{\circ}$ (i.e. $0^{\circ}$ for vertical and $90^{\circ}$ for perpendicular angle with tree stem). Crown base height $(\mathrm{CBH}, \mathrm{cm})$ was defined as the lowest whorl having at least one living branch (criteria: green needles, above which all main branches should be alive). We only considered the living branches, because pruning of dead branches was carried out in the field experiment during winter 2005-2006 before we harvested our study material.

The intra-ring wood densities were measured from pith to bark for each sample tree by the ITRAX X-ray microdensitometer (Cox Analytical Systems, Göteborg, Sweden) at the University of Eastern Finland, School of Forest Sciences. For this purpose, rectangular wood specimens of $5 \mathrm{~mm} \times 5 \mathrm{~mm}$ size were cut out from pith to bark (into north direction) of the stem discs taken at $1 \mathrm{~m}$ above ground. After stabilising the wood specimens for a few weeks to have a moisture content of $12 \%$ (air dry), they were scanned in batches using the ITRAX (for further detail see Peltola et al., 2009). For each sample tree, the average wood density was obtained by averaging the measured wood density profile from pith to bark. 
Table II. Effects of spacing (S), genetic entry (GE), origin group $(\mathrm{OG})$ and their interaction (spacing $\times$ genetic entry, spacing $\times$ origin group) for diameter at breast height $(\mathrm{DBH})$, tree height $(\mathrm{H})$, stem volume $(\mathrm{V})$, wood density (WD), and living branches as an average for all tree: number of branches (NLB), average branch length (ABL), relative crown base height (RCBH), relative cumulated branch area (RCBA), average branch angle (ABA) and relative average branch diameter (RABD).

\begin{tabular}{lccccc}
\hline & \multicolumn{5}{c}{$F$-values } \\
\cline { 2 - 6 } Traits & $\mathrm{S}$ & $\mathrm{GE}$ & $\mathrm{OG}$ & $\mathrm{S} \times \mathrm{GE}$ & $\mathrm{S} \times$ OG \\
DBH & $7.461^{*}$ & 0.121 & 0.168 & 0.520 & 0.269 \\
H & $9.398^{*}$ & $7.128^{*}$ & $12.927^{*}$ & 0.579 & 0.957 \\
V & $3.731^{*}$ & 0.312 & 0.416 & 0.620 & 0.706 \\
WD & $4.786^{*}$ & 1.864 & $4.318^{*}$ & $7.160^{*}$ & 0.661 \\
NLB & $3.449^{*}$ & 1.334 & $3.124^{*}$ & 1.643 & $3.389^{*}$ \\
ABL & $7.287^{*}$ & 1.756 & $3.726^{*}$ & 0.440 & 0.421 \\
RCBH & $6.197^{*}$ & 0.372 & 0.421 & 1.097 & 2.216 \\
RCBA & $11.614^{*}$ & 1.572 & $3.111^{*}$ & 1.320 & 0.202 \\
ABA & 3.025 & 0.619 & 1.291 & 0.543 & 1.067 \\
RABD & 3.020 & 2.286 & $5.180^{*}$ & 1.396 & 1.619 \\
\hline
\end{tabular}

${ }^{*}$ Significance of $F$-ratio $p<0.05$.

\subsection{Data analyses}

Based on measured branch characteristics the following variables were calculated for each sample tree: (i) average branch diameter (ABD, cm); (ii) average branch angle (ABA, degrees); (iii) average branch length $(\mathrm{ABL}, \mathrm{cm})$; (iv) relative average branch diameter $(\mathrm{RABD}=\mathrm{ABD} / \mathrm{DBH}) ;(\mathrm{v})$ cumulative cross-sectional branch area (CBA); based on cross sectional areas of individual branches (assuming diameter of branches circular); (vi) relative cumulative crosssectional branch area $(\mathrm{RCBA}=\mathrm{CBA} / \mathrm{CST} \times 100 \%$, where $\mathrm{CST}$ is the stem surface area calculated by dividing the stem into three truncated cones), and (vii) total number of living branches (NLB). Furthermore, it was determined the branch free stem height in relation to tree height $(\mathrm{RCBH}=\mathrm{CBH} / \mathrm{H}, \mathrm{CBH}$ being the crown base height).

Statistical analyses were carried out using the SPSS statistical program package 16.0 (SPSS for Windows, version 16.0, SPSS, Chicago, IL). Differences in yield traits (DBH, H, V), averages for branch characteristics (ABD, ABA, ABL, RABD, CBA, RCBA, $\mathrm{NLB})$, branch free stem height in relation to tree height $(\mathrm{RCBH})$, as well as average wood density (WD) between genetic entries and origin groups (i.e. northern, central and southern origins, see more details Tab. I) in each spacing were tested with a one-way ANOVA, by applying a pairwise analysis (with a Tukey pairwise test, $p<0.05$ ).

The homogeneity of the variance (Levene's test of equality of error variances) and normality of the data (Kolmogorov-Smirnov test) were also tested. However, due to a lack of homogeneity of variances for ABL, the Games-Howell post-hoc test was applied. To test the simultaneous effects of genetic entry or origin group and spacing we applied a two-way ANOVA.

A mixed modelling approach was also applied to study the effects of spacing, genetic entry/origin group and branch age (whorl number) on the average branch diameter and branch angle. This approach allowed us to take into account the hierarchical structure of the measurements (see e.g. Mäkinen and Colin, 1998) controlling the source of variation inside clusters (whorls of individual trees) and between them (spacing and genetic entry or origin group). In the mixed modelling approach tree size was used as a covariate (DBH) and correspondingly individual sample trees as a random effect.

The general form of the model is as follows,

$$
Y=A \alpha+B \beta+\varepsilon
$$

where $Y$ is a vector with the observation for average branch diameter or average branch angle; $A$ is a matrix of fixed effects with $\alpha$ as an associate vector; while $B$ is the matrix with random effects with $\beta$ as its associate vector, and $\varepsilon$ is a vector of error terms.

The relationships between different traits were examined for the different genetic entries using phenotypic correlations, which were computed using the Pearson's correlation method; $r_{p}=\sigma_{p 1 p 2} /\left(\sigma_{p 1} \times\right.$ $\left.\sigma_{p 2}\right)$, where $\sigma_{p 1 p 2}$ is the phenotypic covariance between properties 1 and 2 , while $\sigma_{p 1}$ and $\sigma_{p 2}$ are the phenotypic standard deviations for properties 1 and 2, respectively. Correlations were expected to be significant at $p<0.05$ level. The $r_{p}$ was computed for individual genetic entries in a similar way as was done in our previous work for Scots pine (Gort et al., 2009; Peltola et al., 2009). We calculated phenotypic correlations, because the relatively small number of sample trees available for each genetic entry and spacing did not support the calculation of genetic correlations (Hannrup et al., 2000; Klein et al., 1973).

\section{RESULTS}

\subsection{Yield traits, average wood density and branch characteristics}

Spacing significantly affects $(p<0.05)$ all the yield traits, i.e. height, diameter at breast height and stem volume (Tab. II). In spacing 3 (with stand density of 4000 trees ha $^{-1}$ ), DBH and $\mathrm{V}$ are, on average, 15-16\% and $20 \%$ smaller, respectively, but $\mathrm{H}$ 5-7\% higher compared to spacing 1 and 2 (with stand densities of 2000 and 2000-2 500 trees $\mathrm{ha}^{-1}$ ). Unlike DBH and $\mathrm{V}, \mathrm{H}$ is also affected by the genetic entry and origin group (Tab. II). In all three spacings, the central origin shows the highest $\mathrm{H}$ on average (for spacing 1 and 2, $p<0.05$ ) (Tab. III). Average wood density is affected by spacing and origin group, but not by the genetic entry (Tab. II). Among the origin groups, the southern one shows the lowest WD in all three spacings. Furthermore, the widest spacing (spacing 3) shows, on average, the lowest WD, regardless of genetic entry or origin group (Tab. III). 
Table III. Mean and standard deviation (sd) for diameter at breast height (DBH, mm), tree height $(\mathrm{H}, \mathrm{m})$, stem volume $\left(\mathrm{V}, \mathrm{m}^{3}\right)$ and wood density (WD, $\mathrm{g} \mathrm{cm}^{-3}$ ) in spacing 1, 2 and 3 (current stand density of $2000,2000-2500$ and 4000 trees ha $^{-1}$, respectively) and for all spacings. Different letters indicate differences among origin groups $(\mathrm{OG})$ within each spacing, Tukey $(p<0.05)$.

\begin{tabular}{|c|c|c|c|c|c|}
\hline & & $\overline{\mathrm{DBH}}$ & $H$ & $\bar{V}$ & WD \\
\hline & OG & Mean \pm sd & Mean $\pm \mathrm{sd}$ & Mean \pm sd & Mean \pm sd \\
\hline \multirow[t]{4}{*}{ Spacing 1} & Northern & $140 \pm 26 a$ & $11.9 \pm 7 \mathrm{a}$ & $0.10 \pm 0.04 a$ & $0.386 \pm 0.03 a$ \\
\hline & Central & $137 \pm 17 \mathrm{a}$ & $12.9 \pm 9 b$ & $0.11 \pm 0.02 \mathrm{a}$ & $0.372 \pm 0.03 \mathrm{ab}$ \\
\hline & Southern & $135 \pm 27 a$ & $11.7 \pm 7 a$ & $0.09 \pm 0.04 a$ & $0.360 \pm 0.02 b$ \\
\hline & All & $137 \pm 23$ & $12.2 \pm 9$ & $0.10 \pm 0.03$ & $0.373 \pm 0.02$ \\
\hline \multirow[t]{4}{*}{ Spacing 2} & Northern & $133 \pm 21 \mathrm{a}$ & $11.2 \pm 8 \mathrm{a}$ & $0.09 \pm 0.03 a$ & $0.385 \pm 0.03 a$ \\
\hline & Central & $141 \pm 25 \mathrm{a}$ & $12.6 \pm 7 b$ & $0.11 \pm 0.04 a$ & $0.386 \pm 0.02 a$ \\
\hline & Southern & $135 \pm 23 a$ & $11.9 \pm 7 \mathrm{ab}$ & $0.09 \pm 0.03 a$ & $0.369 \pm 0.02 \mathrm{a}$ \\
\hline & All & $136 \pm 22$ & $11.9 \pm 9$ & $0.10 \pm 0.03$ & $0.380 \pm 0.02$ \\
\hline \multirow[t]{4}{*}{ Spacing 3} & Northern & $121 \pm 36 a$ & $12.5 \pm 11 \mathrm{a}$ & $0.09 \pm 0.05 a$ & $0.368 \pm 0.02 \mathrm{a}$ \\
\hline & Central & $112 \pm 10 \mathrm{a}$ & $13.3 \pm 6 a$ & $0.07 \pm 0.01 \mathrm{a}$ & $0.376 \pm 0.01 \mathrm{a}$ \\
\hline & Southern & $113 \pm 21 \mathrm{a}$ & $12.7 \pm 9 a$ & $0.07 \pm 0.03 \mathrm{a}$ & $0.360 \pm 0.03 a$ \\
\hline & All & $115 \pm 25$ & $12.8 \pm 9$ & $0.08 \pm 0.04$ & $0.368 \pm 0.02$ \\
\hline \multirow{3}{*}{ All spacing } & Northern & $131 \pm 29 a$ & $11.9 \pm 10 \mathrm{a}$ & $0.09 \pm 0.04 a$ & $0.380 \pm 0.03 a$ \\
\hline & Central & $130 \pm 22 \mathrm{a}$ & $12.9 \pm 8 b$ & $0.09 \pm 0.03 a$ & $0.378 \pm 0.02 \mathrm{a}$ \\
\hline & Southern & $128 \pm 25 a$ & $12.1 \pm 8 \mathrm{a}$ & $0.09 \pm 0.03 a$ & $0.363 \pm 0.02 b$ \\
\hline
\end{tabular}

Total number of living branches, average branch length, relative crown base height and relative cumulative cross-sectional branch area are all affected by spacing $(p<0.05)$. In spacing 2 , the NLB is, on average, 9-17\% higher than in spacing 1 and 3, and it also has the longest branches, on average (Tab. IV). Furthermore, RCBA is, on average, 23-46\% lower and RCBH 5-8\% higher in spacing 3 than in spacings 1 and 2 .

Average branch characteristics such as NBL, ABL, RABD and RCBA are also affected by the origin group, but not by the genetic entry. In a similar way, no spacing $\times$ genetic entry interaction is found, but spacing $\times$ origin group interaction affects NLB (Tab. II). Northern origin (average for genetic entries 15 and 16) has the lowest NLB in spacing 1 and 2, while in spacing 3 southern origin has the lowest NLB. Additionally, southern origin has the lowest ABL and RABD, regardless of spacing. Spacing significantly affects RCBH, which is the highest in the densest spacing (spacing 3), while genetic entries and origin groups have no effect on RCBH.

\subsection{Branch characteristics along the stem}

The variation observed in average branch diameter along the stem is significantly affected by the spacing, branch age (whorl number) and origin group, but not by genetic entry. Regarding ABD in each whorl, the northern origin differs significantly $(p<0.05)$ from the southern one (Tab. V, Fig. 1). As a comparison, the variation observed in average branch angle along the stem is affected by the branch age (whorl) and genetic entry or origin group, but not by spacing (Tab. V). Moreover, in both variables, ABD and ABA, the northern origin differs significantly from the southern one (Fig. 2).

\subsection{Phenotypic correlations between different traits}

The phenotypic correlation for tree height and diameter at breast height (DBH) with stem volume is statistically signifi- cant ( $p<0.05)$, ranging from moderate to high. However, $\mathrm{V}$ is calculated based on DBH and $\mathrm{H}$. The diameter at breast height does not correlate with $\mathrm{H}$ (Tab. VI). Average wood density correlates negatively with DBH and V. In general, DBH and V also correlate significantly with all the studied branch characteristics (no correlation between V and ABA). On the contrary, $\mathrm{H}$ correlates significantly only with relative average branch diameter. For instance, the correlations between DBH with average branch length and number of living branches is moderate and positive, whereas with relative crown base height it is moderate, but negative $(p<0.05)$.

Among the branch characteristics, ABL and NLB correlate negatively with $\mathrm{RCBH}$, and positively with ABA. RABD and RCBA correlate positively with ABL, but negatively with ABA $(p<0.05)$. RABD is also negatively correlated with $\mathrm{H}$, DBH and V. Furthermore, RCBA is positively correlated with $\mathrm{DBH}$ and $\mathrm{V}$, but not with $\mathrm{H}$. However, most of these correlations are low to moderate.

\section{DISCUSSION AND CONCLUSIONS}

Initial spacing, tending of seedling stand and thinning can be used to control the growth, mortality and self-pruning of branches, especially in the most valuable lower part of the stem in tree species like Scots pine (e.g. Mörling, 2002; Ståhl, 1988). However, because the growth of stem and branches correlates strongly (and positively), branch size could usually be reduced only at the expense of total tree growth (e.g. Mäkinen, 1999a; Mäkinen and Colin, 1998). On the other hand, different genetic entries may show differences in their stem growth and branch characteristics, which was found previously, for example, in Scots pine (e.g. Haapanen et al., 1997; Velling, 1988). In our work, Kanerva pine (plus tree S1101) was a father for all genetic entries, while a mother represented Finnish plus trees grown in southern, central and northern Finland. Therefore, we expected to find differences in branch characteristics 
Table IV. Mean and standard deviation (sd) for relative crown base height (RCBH), relative cumulative cross-sectional branch area (RCBA), average branch length (ABL, cm), number of living branches (NLB), average branch angle (ABA, degrees) and relative average branch diameter (RABD) in spacing 1, 2 and 3 (current stand density of 2000, $2000-2500$ and 4000 trees ha $^{-1}$, respectively) and for all spacing. Different letters indicate differences among origin groups $(\mathrm{OG})$ within each spacing, Tukey $(p<0.05)$.

\begin{tabular}{lccccccc}
\hline & & NLB & ABL & RCBH & RCBA & ABA & RABD \\
\cline { 2 - 7 } & OG & Mean $\pm \mathrm{sd}$ & Mean $\pm \mathrm{sd}$ & Mean $\pm \mathrm{sd}$ & Mean $\pm \mathrm{sd}$ & Mean $\pm \mathrm{sd}$ & Mean $\pm \mathrm{sd}$ \\
\hline Spacing 1 & Northern & $23.4 \pm 5.6 \mathrm{a}$ & $95 \pm 36 \mathrm{a}$ & $0.57 \pm 0.06 \mathrm{a}$ & $0.21 \pm 0.06 \mathrm{a}$ & $35 \pm 10 \mathrm{a}$ & $0.165 \pm 0.01 \mathrm{a}$ \\
& Central & $25.9 \pm 6.3 \mathrm{ab}$ & $91 \pm 27 \mathrm{a}$ & $0.62 \pm 0.06 \mathrm{a}$ & $0.18 \pm 0.05 \mathrm{a}$ & $34 \pm 13 \mathrm{a}$ & $0.165 \pm 0.01 \mathrm{a}$ \\
& Southern & $30.9 \pm 6.9 \mathrm{~b}$ & $78 \pm 24 \mathrm{a}$ & $0.59 \pm 0.05 \mathrm{a}$ & $0.18 \pm 0.07 \mathrm{a}$ & $41 \pm 14 \mathrm{a}$ & $0.142 \pm 0.02 \mathrm{a}$ \\
& All & $26.7 \pm 7.0$ & $88 \pm 36$ & $0.59 \pm 0.06$ & $0.19 \pm 0.06$ & $37 \pm 11$ & $0.157 \pm 0.02$ \\
Spacing 2 & Northern & $24.9 \pm 4.9 \mathrm{a}$ & $104 \pm 28 \mathrm{a}$ & $0.58 \pm 0.04 \mathrm{a}$ & $0.17 \pm 0.05 \mathrm{a}$ & $39 \pm 8 \mathrm{a}$ & $0.158 \pm 0.02 \mathrm{a}$ \\
& Central & $28.8 \pm 6.0 \mathrm{ab}$ & $102 \pm 46 \mathrm{a}$ & $0.54 \pm 0.06 \mathrm{a}$ & $0.16 \pm 0.06 \mathrm{a}$ & $47 \pm 14 \mathrm{a}$ & $0.146 \pm 0.04 \mathrm{a}$ \\
& Southern & $32.8 \pm 6.5 \mathrm{~b}$ & $76 \pm 43 \mathrm{a}$ & $0.60 \pm 0.05 \mathrm{a}$ & $0.15 \pm 0.05 \mathrm{a}$ & $46 \pm 19 \mathrm{a}$ & $0.137 \pm 0.04 \mathrm{a}$ \\
Spacing 3 & All & $29.0 \pm 6.8$ & $94 \pm 28$ & $0.57 \pm 0.05$ & $0.16 \pm 0.06$ & $44 \pm 12$ & $0.147 \pm 0.02$ \\
& Northern & $25.5 \pm 8.1 \mathrm{a}$ & $70 \pm 23 \mathrm{a}$ & $0.62 \pm 0.06 \mathrm{a}$ & $0.15 \pm 0.06 \mathrm{a}$ & $35 \pm 8 \mathrm{a}$ & $0.150 \pm 0.02 \mathrm{a}$ \\
& Central & $26.9 \pm 3.3 \mathrm{a}$ & $68 \pm 19 \mathrm{a}$ & $0.62 \pm 0.04 \mathrm{a}$ & $0.10 \pm 0.03 \mathrm{a}$ & $39 \pm 7 \mathrm{a}$ & $0.142 \pm 0.01 \mathrm{a}$ \\
& Southern & $21.7 \pm 4.7 \mathrm{a}$ & $61 \pm 24 \mathrm{a}$ & $0.63 \pm 0.04 \mathrm{a}$ & $0.12 \pm 0.04 \mathrm{a}$ & $35 \pm 12 \mathrm{a}$ & $0.147 \pm 0.01 \mathrm{a}$ \\
& All & $24.7 \pm 6.0$ & $66 \pm 22$ & $0.62 \pm 0.05$ & $0.13 \pm 0.05$ & $36 \pm 9$ & $0.146 \pm 0.02$ \\
\hline All spacing & Northern & $24.6 \pm 6.3 \mathrm{a}$ & $90 \pm 32 \mathrm{a}$ & $0.59 \pm 0.06 \mathrm{a}$ & $0.18 \pm 0.06 \mathrm{a}$ & $36 \pm 9 \mathrm{a}$ & $0.158 \pm 0.02 \mathrm{a}$ \\
\hline & Central & $27.2 \pm 5.1 \mathrm{a}$ & $87 \pm 33 \mathrm{a}$ & $0.60 \pm 0.06 \mathrm{a}$ & $0.15 \pm 0.05 \mathrm{a}$ & $40 \pm 12 \mathrm{a}$ & $0.151 \pm 0.02 \mathrm{ab}$ \\
\hline & Southern & $28.5 \pm 8.2 \mathrm{a}$ & $71 \pm 26 \mathrm{a}$ & $0.60 \pm 0.06 \mathrm{a}$ & $0.15 \pm 0.06 \mathrm{a}$ & $41 \pm 13 \mathrm{a}$ & $0.142 \pm 0.01 \mathrm{~b}$ \\
\hline
\end{tabular}

Table V. $F$-value for intercept, spacing, genetic entry (GE), whorl, whorl $\times$ GE interaction, origin group $(\mathrm{OG})$ and whorl $\times$ OG interaction for average branch diameter (ABD) and average branch angle (ABA).

\begin{tabular}{lccccc}
\hline Variables & Intercept & Spacing & GE & Whorl & Whorl $\times$ GE \\
\hline ABD & $3427.04^{*}$ & $11.66^{*}$ & - & $186.01^{*}$ & $2.38^{*}$ \\
ABA & $2802.95^{*}$ & - & $3.61^{*}$ & $66.25^{*}$ & - \\
\hline Variables & Intercept & Spacing & OG & Whorl & Whorl $\times$ OG \\
\hline ABD & $3436.76^{*}$ & $12.16^{*}$ & $3.80^{*}$ & $173.52^{*}$ & - \\
\hline ABA & $2896.99^{*}$ & - & $8.74^{*}$ & $69.97^{*}$ & $2.50^{*}$ \\
\hline
\end{tabular}

${ }^{*}$ Significance $p<0.05$. (-) Variables with no significance effects removed from model.
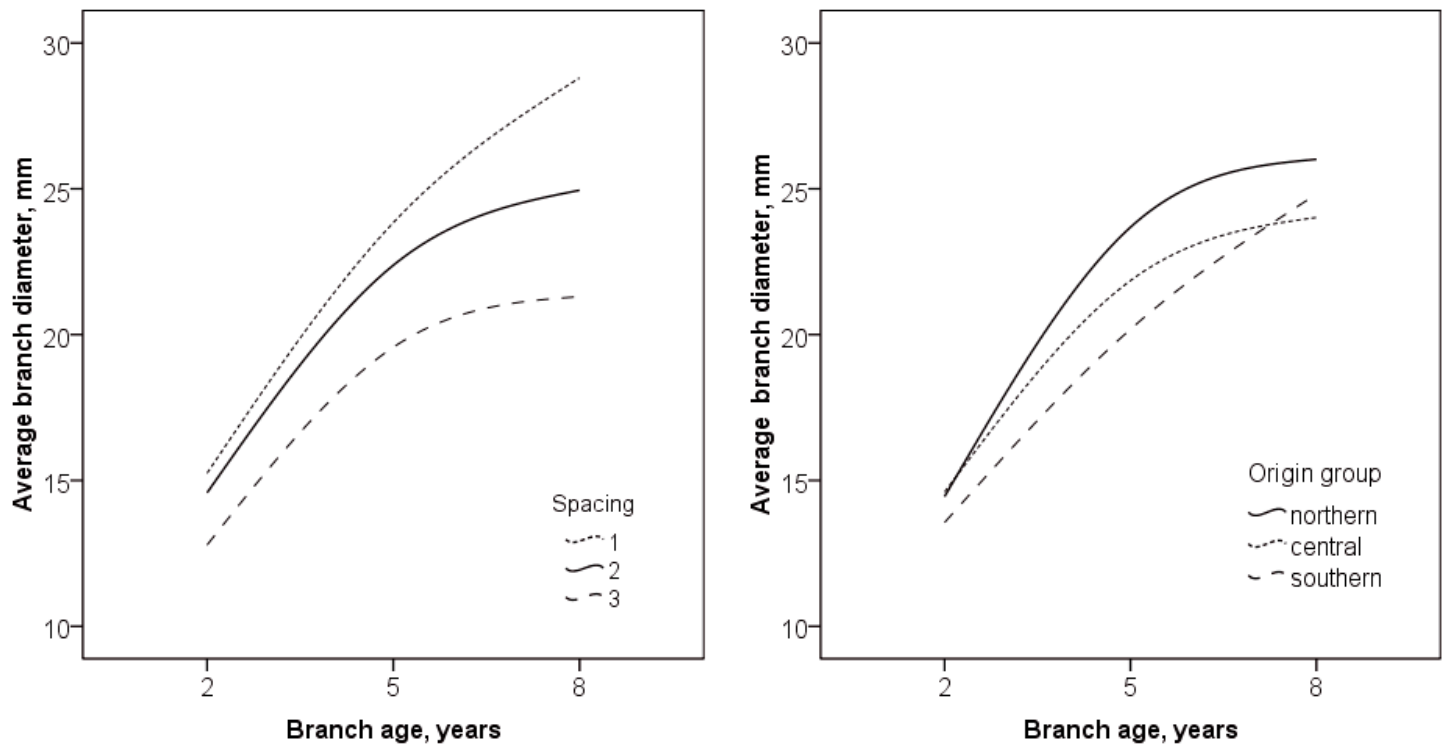

Figure 1. Average branch diameter (ABD) modelled as a function of branch age for: (i) spacing 1, 2 and 3 (current stand density of 2000 , 2000-2 500 and 4000 trees ha ${ }^{-1}$, respectively) on average for all genetic entries (left); and (ii) different origin groups (southern, central and northern) on average for all three spacings (right). 
Table VI. Correlations between diameter at breast height (DBH), tree height $(H)$, stem volume $(V)$, wood density (WD), number of living branches (NLB), average branch length (ABL), relative crown base height (RCBH), relative cumulative cross-sectional branch area (RCBA), average branch angle (ABA) and relative average branch diameter (RABD) regardless of spacing.

\begin{tabular}{lccccccccc}
\hline Traits & $H$ & $V$ & WD & NLB & ABL & RCBH & RCBA & ABA & RABD \\
\hline DBH & 0.197 & $0.946^{*}$ & $-0.290^{*}$ & $0.445^{*}$ & $0.560^{*}$ & $-0.535^{*}$ & $0.573^{*}$ & $0.213^{*}$ & $-0.209^{*}$ \\
$H$ & & $0.389^{*}$ & -0.178 & 0.123 & -0.017 & 0.037 & -0.168 & 0.087 & $-0.225^{*}$ \\
$V$ & & & $-0.324^{*}$ & $0.412^{*}$ & $0.477^{*}$ & $-0.450^{*}$ & $0.484^{*}$ & 0.201 & $-0.212^{*}$ \\
WD & & & & -0.029 & -0.013 & 0.021 & -0.119 & -0.075 & 0.167 \\
NLB & & & & & 0.154 & $-0.256^{*}$ & $0.243^{*}$ & $0.222^{*}$ & $-0.282^{*}$ \\
ABL & & & & & & $-0.628^{*}$ & $0.357^{*}$ & $0.451^{*}$ & $0.262^{*}$ \\
RCBH & & & & & & & $-0.300^{*}$ & $-0.528^{*}$ & 0.122 \\
RCBA & & & & & & & $-0.234^{*}$ & $0.392^{*}$ \\
ABA & & & & & & & & $-0.362^{*}$ \\
\hline
\end{tabular}

* Significance $p<0.05$.

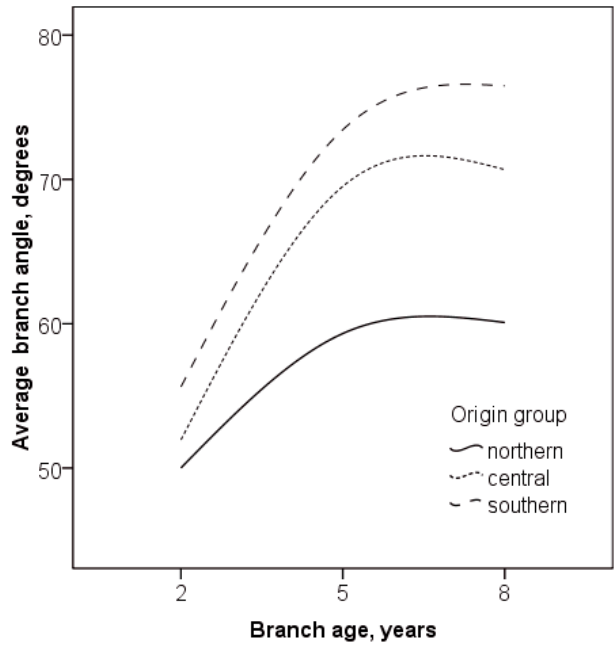

Figure 2. Average branch angle (ABA) modelled as a function of branch age over all three spacings for different origin groups.

as well as in other traits (yield and wood density) between these crossings, and regardless of spacing.

In our work, spacing affects all the yield traits $(p<0.05)$, unlike genetic entry or origin group. The diameter at breast height and stem volume are, on average, the highest in the two widest spacings (in which stand density differs significantly only before tending of seedling stand), while in the densest one the average tree height is the highest. Regardless of spacing, central origin shows, on average, the highest $\mathrm{H}$. This might result from the fact that the mother trees of trees representing central origin have also been growing in a similar climatic conditions unlike those of southern and northern ones. Contradictorily to our work, Persson et al. (1995) reported differences in stem volume growth in different genetic entries of Scots pine.

Spacing and origin group also affects average wood density, unlike individual genetic entry. In our work, the northern origin has, on average, the highest WD, regardless of the spacing (Fig. 3). This result is in line with other previous findings where northern provenances transferred to the south have, on average, higher WD than the local ones (Ståhl and Ericson,
1991). Additionally, Persson et al. (1995) found differences among genetic entries and spacings for WD in Scots pine. Likewise, Zubizarreta Gerendiain et al. (2007, 2009) observed differences for WD among origin groups and/or genetic entries in Norway spruce (Picea abies) grown in Finland.

Similar to the yield and wood density traits, the relative values for relative crown base height, cumulative cross-sectional branch area and number of living branches (i.e. NLB) are affected by spacing $(p<0.05)$. However, for example, RABD is not affected by the spacing as such, because, along with changes in DBH, branch size also changed and vice versa. In the densest spacing, RCBA (in sampled whorls 2, 5 and 8) is lower than in the two widest spacings. This is in line with the previous findings of Kellomäki and Tuimala (1981), i.e. the branch cross sectional area per stem unit is negatively correlated to the stand density. This result could be explained by the fact that the dynamics of crown development (and thus, branches) depends on the light available in the lower canopy (Kellomäki et al., 1999). Branch characteristics such as relative average branch diameter and relative cumulative crosssectional branch area could, in general be taken as important factors from the point of view of timber quality. In our work, they are both affected by the origin groups, but not by the genetic entry. The northern origin has, on average, the highest RABD and RCBA, but also DBH (Fig. 3).

The differences observed in the average diameter of living branches along the stem (between whorls 2 and 8 ) could be explained by the branch age, spacing and origin group. The densest spacing has less light interception especially in the lower crown, reducing the growth rate of the lowest branches, compared to the wider spacing (e.g. Kellomäki and Oker-Blom, 1983). Average branch angle of living branches over the stem can be explained by the branch age and genetic entry/origin group, but not by spacing. The ABD and ABA from the northern origin differs clearly from the other origins. In previous studies in Scots pine (Haapanen et al., 1997; Hannrup et al., 2000), the heritability estimates have been considerably lower for branch characteristics, meaning that they could be influenced more by the environmental conditions (e.g. availability of light) and silvicultural management such as spacing, than by genetics. 

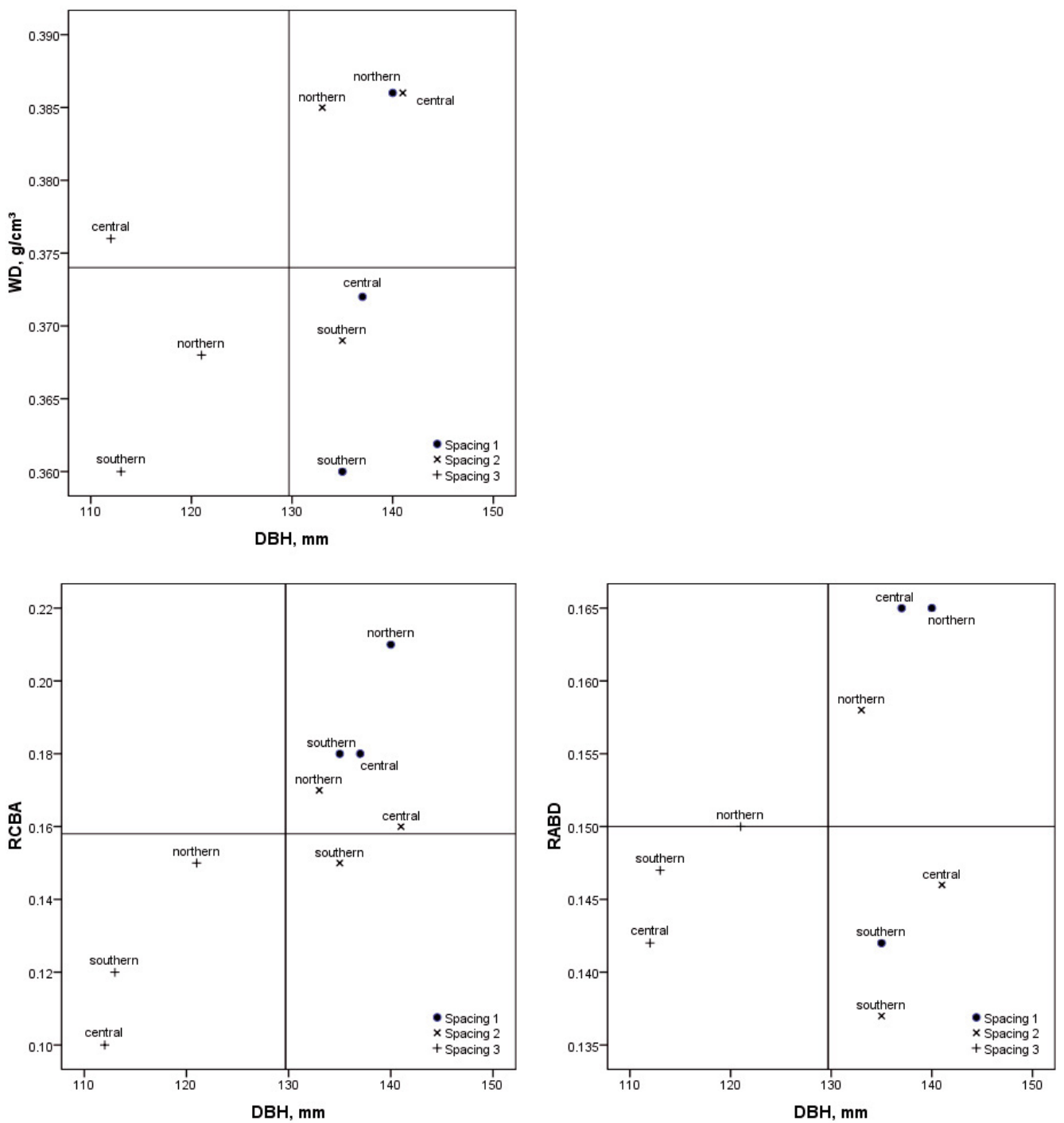

Figure 3. Relationships between diameter at breast height $(\mathrm{DBH}, \mathrm{mm})$ and overall wood density $\left(\mathrm{g} / \mathrm{cm}^{3}\right)$, relative cross-sectional branch area (RCBA, dimensionless) and relative average branch diameter (RABD, dimensionless) for the different spacings and origin groups. The lines represent the average values over all the origins for each trait.

The phenotypic correlation for tree height and diameter at breast height with stem volume are positive and ranges from moderate to high in this work (however, $\mathrm{V}$ is calculated based on $\mathrm{H}$ and $\mathrm{DBH}$ ). Furthermore, average wood density correlates negatively with $\mathrm{DBH}$ and $\mathrm{V}$, which agrees with many other previous studies in Scots pine, as well as in many other coniferous species (e.g. Hannrup et al., 2000; Kang et al., 2004; Zubizarreta Gerendiain et al., 2007). RABD also correlates negatively with $\mathrm{H}, \mathrm{DBH}$ and $\mathrm{V}$, whereas RCBA correlates positively with $\mathrm{DBH}$ and $\mathrm{V}$, but not with $\mathrm{H}$. In the same way, Haapanen et al. (1997) found that DBH and average branch diameter showed a reasonably high positive correlation. However, many of the correlations of yield traits with branch characteristics and among branch characteristics are from low to moderate, although they are significant in our work $(p<0.05)$.
The phenotypic correlations between WD and branch characteristics are also close to zero, and in many cases nonsignificant, which is in agreement with previous findings e.g. by Hannrup et al. (2000). Few studies are available on the phenotypic or genetic correlations between yield and stem quality traits and average wood density in Scots pine (Haapanen et al., 1997; Hannrup et al., 2000). In general, those also have reported no, or weak negative, genetic/phenotypic correlations between traits such as branch angle, branch thickness, number of branches, stem straightness and average wood density.

To conclude, despite the fact that all the genetic entries had, in our work, Kanerva pine as a parent tree we could still find some differences in yield, wood density traits and branch characteristics among different origin groups grown in the same spacing, but not between individual genetic entries. Nonetheless, in our study the number of replicates for each genetic 
entry was limited, which could partly explain this latter result. Furthermore, in line with previous findings, we could also find that the growth of branches can only be affected at expense of stem growth for instance by controlling the spacing. It would also have been valuable to consider the effects of spacing and genetic entry/origin group on characteristics of dead branches and their presence in the lower crown. Unfortunately, this was not possible due to earlier pruning of dead branches.

In the future, it may become necessary to balance the gain/loss between the quantity and quality of raw material (e.g. stem volume, average wood density and branch characteristics of trees), considering, in detail, the final target of wood production (e.g. pulp wood or sawn timber products). By doing so, it may even be possible to identify some genetic entries and their site specific management that could be the most suited to particular product types or processes. However, for this purpose, more detailed studies on this research area are needed, and based on larger number of genetic entries (representing wide geographical range), which have also grown under different climatic and management conditions (e.g. sites, silvicultural treatments) over longer period.

Acknowledgements: This work is related to the work done by the Centre of Excellence for Boreal Forest Management Research led by Prof. Seppo Kellomäki at the School of Forest Sciences, Faculty of Sciences and Forestry, University of Eastern Finland (formerly University of Joensuu, Faculty of Forest Sciences). The authors would like to thank the Finnish Forest Research Institute (FFRI) for providing the material. Mr Jarmo Pennala and Ms Marja Kuskelin, from the University of Eastern Finland, School of Forest Sciences, are thanked for helping us in harvesting of the sample trees. Mr Jarmo Pennala is also thanked for X-ray measurements and Dr. David Gritten for the English revision. The support provided by the University of Eastern Finland, School of Forest Sciences, the Graduate School for Forest Sciences, and the Finnish Forest Research Institute are also gratefully acknowledged.

\section{REFERENCES}

Gort J., Zubizarreta Gerendiain A., Peltola H., Pulkkinen P., Routa J., and Jaatinen R., 2009. Differences in fibre properties in Scots pine (Pinus sylvestris L.) genetic entries grown at different spacing and sites. Silva Fenn. 43: 355-368.

Haapanen M. and Pöykkö T., 1993. Genetic relationship between growth and quality traits in an 8-year-old half-sib progeny trial of Pinus sylvestris. Scan. J. For. Res. 8: 305-312.

Haapanen M., Velling P., and Annala M.-J., 1997. Progeny trial estimates of genetic parameters for growth and quality traits in Scots pine. Silva Fenn. 31: 3-12.

Hannrup B., Ekberg I., and Persson A., 2000. Genetic correlations among wood, growth capacity and stem traits in Pinus silvestris. Scan. J. For. Res. 15: 161-170.

Ikonen V., Kellomäki S., and Peltola H., 2009. Sawn timber properties of Scots pine as affected by initial stand density, thinning and pruning: a simulation based approach. Silva Fenn. 43: 411-431.

Kang Y.K., Zhang S.Y., and Mansfield S.D., 2004. The effects of initial spacing on wood density, fibre and pulp properties in jack pine (Pinus banksiana Lamb.). Holzforschung 58: 455-463.

Kellomäki S. and Tuimala A., 1981. Puuston tiheyden vaikutus puiden oksikkuuteen taimikko- ja riukuvaiheen männiköissä (in Finnish). [Abstract: Effect of stand density on branchiness of young Scots pines]. Folia For. 478 p.
Kellomäki S. and Oker-Blom P., 1983. Canopy structure and light climate in a young Scots pine stand. Silva Fenn. 17: 1-21

Kellomäki S., Ikonen V.-P., Peltola H., and Kolström T., 1999. Modelling the structural growth of Scots pine with implications for wood quality. Ecol. Model. 112: 117-134.

Klein T.W., Defries J.C., and Finkbeiner C.T., 1973. Heritability and genetic correlations: standard error of estimates and sample size. Behav. Genet. 3: 355-364.

Kärki L., 1985. Crop tree ideotypes and harvest index should be the basis of selection in cultivated trees. Foundation of Forest Tree Breeding in Finland, Annual report 1984, pp. 20-23.

Laasasenaho J., 1982. Taper curve and volume functions for pine, spruce and birch. Comm. Inst. For. Fenn. 108: 11-108.

Mäkinen H., 1999a. Growth, suppression, death, and self-pruning of branches of Scots pine in southern and central Finland. Can. J. For. Res. 29: 585-594.

Mäkinen H., 1999b. Effect of stand density on radial growth of branches of Scots pine in southern and central Finland. Can. J. For. Res. 29: $1216-1224$.

Mäkinen, H. and Colin F., 1998. Predicting branch angle and branch diameter of Scots pine from usual tree measurements and stand structural information. Can. J. For. Res. 28: 1686-1696.

Mörling T., 2002. Evaluation of annual ring width and ring density development following fertilisation and thinning of Scots pine. Ann. For. Sci. 59: 29-40.

Peltola H., Gort J., Pulkkinen P., Zubizarreta Gerendiain A., Jouni Karppinen J., and Ikonen V.-P., 2009. Differences in growth and wood density traits in Scots pine (Pinus sylvestris L.) genetic entries grown at different spacing and sites. Silva Fenn. 43: 339-354.

Persson B., Persson A., Ståhl E.G., and Karlmats U., 1995. Wood quality of Pinus sylvestris progenies at various spacings. For. Ecol. Manage. 76: $127-138$.

Pöykkö T., 1993. Selection criteria in Scots pine breeding with special reference to ideotype. The Foundation for Forest Tree Breeding in Finland, Report 6, 66 p.

Pöykkö T. and Velling P., 1993. Inheritance of the narrow-crowned Scots pine E 1101, "Kanerva pine". Silva Fenn. 27: 219-226.

Ståhl E.G., 1988. Transfer effect and variations in basic density and tracheid length of Pinus sylvestris L. populations. Stud. For. Suec. 180, $15 \mathrm{p}$.

Ståhl E.G. and Ericson B., 1991. Inheritance of wood properties. In: M. Giertych and C. Mátyás, (Ed.), Genetics of Scots Pine. Developments in Plant Genetics and Breeding, Vol. 3, Elsevier, Amsterdam, pp. 231-241.

Velling P., 1988. The relationships between yield components in the breeding of Scots pine. Academic Diss., Univ. Helsinki, Helsinki. (in Finnish), 59 p.

Wang T., Aitken S., Rozenberg P., and Millie F., 2000. Selection for improved growth and wood density in Lodgepole Pine: effects on radial patterns of wood variation. Wood Fiber Sci. 32: 391-403.

Wilhelmsson L., Arlinger J., Spångberg K., Lundqvist S.-O., Grahn T., Hedenberg Ö., and Olsson L., 2002. Models for predicting wood properties in stems of Picea abies and Pinus sylvestris in Sweden. Scan. J. For. Res. 17: 330-350.

Zobel B.J. and Talbert J., 1984. Applied forest tree improvement. John Wiley \& Sons, New York, 505 p.

Zobel B.J. and Van Buijtenen J.P. 1989. Wood variation: Its causes and control. Springer-Verlag, Berlin, Germany, 363 p.

Zubizarreta Gerendiain A., Peltola H., Pulkkinen P., and Kellomäki S., 2009. Effects of genetic entry and competition by neighbouring trees on growth and wood properties of cloned Norway spruce (Picea abies). Ann. For. Sci. 66: 806.

Zubizarreta Gerendiain A., Peltola H., Pulkkinen P., Jaatinen R., Pappinen A., and Kellomäki S., 2007. Differences in growth and wood property traits in cloned Norway spruce (Picea abies). Can. J. For. Res. 37: 2600-2611. 